\title{
Review Article \\ Significance of Urinary Proteome Pattern in Renal Allograft Recipients
}

\author{
Sufi M. Suhail ${ }^{1,2}$ \\ ${ }^{1}$ DUKE-NUS Graduate Medical School, Singapore 169857 \\ ${ }^{2}$ Department of Renal Medicine, Singapore General Hospital, 20 College Road, Singapore 169856
}

Correspondence should be addressed to Sufi M. Suhail; grmsms@sgh.com.sg

Received 22 November 2013; Accepted 13 February 2014; Published 13 March 2014

Academic Editor: Wojciech Rowiński

Copyright (c) 2014 Sufi M. Suhail. This is an open access article distributed under the Creative Commons Attribution License, which permits unrestricted use, distribution, and reproduction in any medium, provided the original work is properly cited.

\begin{abstract}
Urinary proteomics is developing as a platform of urinary biomarkers of immense potential in recent years. The definition of urinary proteome in the context of renal allograft and characterization of different proteome patterns in various graft dysfunctions have led to the development of a distinct science of this noninvasive tool. Substantial numbers of studies have shown that different renal allograft disease states, both acute and chronic, could portray unique urinary proteome pattern enabling early diagnosis of graft dysfunction and proper manipulation of immunosuppressive strategy that could impact graft prognosis. The methodology of the urinary proteome is nonetheless not more complex than that of other sophisticated assays of conventional urinary protein analysis. Moreover, the need for a centralized database is also felt by the researchers as more and more studies have been presenting their results from different corners and as systems of organizing these newly emerging data being developed at international and national levels. In this context concept of urinary proteomics in renal allograft recipients would be of significant importance in clinical transplantation.
\end{abstract}

\section{Introduction}

Overt proteinuria is an established prognostic marker in renal allograft recipients associated with allograft dysfunction and graft loss $[1,2]$. However, the early detection of the causes of graft dysfunction and graft loss is important. The current modality for definitive diagnosis of graft abnormalities is graft biopsy [3]. Inherent risk of biopsy on a single transplanted kidney and delay involved in the detailed reporting of the tissue could preclude an early diagnosis of the graft dysfunction and early institution of specific therapy. On the other hand, urinary proteome is a distinct entity from the conventional nosology of proteinuria that has been emerging in recent years $[4,5]$. Urinary proteome constitutes the entire genomic protein content that is excreted in urine in health and disease states. Proteomic urine analysis could predict the diagnosis of renal transplant pathologies early, which could impact the graft function and survival in the long run [5]. Moreover, urinary proteome patterns in transplant patients could differentiate stable graft function from acute tubulointerstitial rejection (AR), urinary tract infection (UTI), acute tubular necrosis (ATN), and calcineurin inhibitor (CNI) toxicity [6] . In addition, characterization of chronic allograft dysfunction into chronic antibody associated rejection (CAAR), interstitial fibrosis tubular atrophy without inflammation (IFTA), chronic recurrent or de-novo glomerulonephritis (GN), and transplant glomerulopathy (TG) could also be predicted by urinary proteome pattern $[7,8]$.

Over the current decade, several proteome data sources have revealed a large pool of discovery and sequencing of previously unexplored urinary peptides and protein chains in health and disease states [9]. Furthermore, system for organizing the data structure of several proteome has also been generated through hierarchical tree that yields highquality protein families which come from various databanks, that is, GenBank, Protein Data Bank (PDB), SwissProt, Protein Information Resource (PIR), and Protein Research Foundation (PRF) [10]. The aim of this general review is to elucidate the aspects of urinary proteome patterns in different renal allograft pathologies. 
TABLE 1: Classification of urinary proteomes based on their molecular weight characteristics.

\begin{tabular}{|c|c|c|c|c|c|}
\hline & Urinary proteome & $\begin{array}{c}\text { Molecular } \\
\text { weight (Da) }\end{array}$ & Sources & Examples & Graft abnormalities \\
\hline 1 & $\begin{array}{l}\text { Smaller molecular } \\
\text { weight }\end{array}$ & 1000 to 20,000 & $\begin{array}{l}\text { Inflammatory and } \\
\text { interstitial cell product. }\end{array}$ & $\begin{array}{l}\text { Interleukins, granzyme, } \\
\text { perforin, and so forth. }\end{array}$ & $\begin{array}{c}\text { AR, ATN, UTI, CNI } \\
\text { toxicity, CAAR, and IFTA. }\end{array}$ \\
\hline 2 & Low molecular weight & 10,000 to 33,000 & Tubular overflow. & $\begin{array}{l}\text { Alpha- } 1 \mu \text {-globulin, } \\
\text { Beta- } 2 \mu \text {-globulin, RBP, } \\
\text { and so forth. }\end{array}$ & $\begin{array}{c}\text { Physiological, UTI, and } \\
\text { ATN. }\end{array}$ \\
\hline 3 & $\begin{array}{l}\text { Middle and high } \\
\text { molecular weight }\end{array}$ & $\begin{array}{l}60,000 \text { to } \\
150,000\end{array}$ & Glomerular leak. & $\begin{array}{l}\text { Albumin, transferrin, } \\
\text { and immuno-globulins. }\end{array}$ & $\begin{array}{l}\text { GN, TG, and mTOR } \\
\text { induced. }\end{array}$ \\
\hline
\end{tabular}

Da: Dalton, AR: acute rejection, ATN: acute tubular necrosis, UTI: urinary tract infection, CNI: calcineurin inhibitor, CAAR: chronic-antibody-associatedrejection with C4d deposits, IFTA: interstitial-nephritis-tubular-atrophy, RBP: retinol binding protein, GN: glomerulonephritis, TG: transplant glomerulopathy, and mTOR: mammalian target of rapamycin.

\section{Overt Proteinuria in Renal Allograft Recipient}

While pretransplant proteinuria from the native kidney disappears rapidly after renal transplantation [11], persistence of overt proteinuria (urine protein creatinine ratio $>0.2 \mathrm{~g} / \mathrm{g}$ ) in renal transplant recipients implies glomerulonephritis (GN), transplant glomerulopathy (TG), and mammalian target of rapamycin (mTOR) induced graft nephropathy. This is strongly associated with poor graft survival $[1,12]$. In chronic kidney disease (CKD), this overt proteinuria could be stratified by qualitative analysis into low molecular weight $(20,000 \mathrm{Da}$ to $33,000 \mathrm{Da})$ tubular protein and middle and high molecular weight $(60,000 \mathrm{Da}$ to $150,000 \mathrm{Da})$ glomerular protein. This stratification enables identification of their association with different types of glomerular and tubular lesions in CKD (Table 1) $[13,14]$. However, similar stratification in renal allograft showed that low molecular weight tubular protein could be present despite good graft function [14], while glomerular proteinuria poses a statistically significant adverse outcome on graft function and survival [2]. Allograft biopsy in transplant glomerulopathy with chronic graft dysfunction (CGD) revealed glomerular abnormalities leading to glomerular type of proteinuria [15]. In one study positive correlation between glomerular proteins and inflammatory cytokines in renal tissue was found in patients with poor graft function [16].

On the other hand, allograft dysfunctions related to acute tubulointerstitial rejection (AR), CNI toxicity, acute tubular necrosis (ATN), interstitial nephritis (IN), urinary tract infections (UTI), chronic antibody associated rejection (CAAR), and interstitial nephritis tubular atrophy (IFTA) are not associated with overt proteinuria. Even though these conditions do not induce significant proteinuria, they are associated with excretion of genomic proteins, known as urinary proteome, that might remain undetected by usual clinical laboratory methods for proteinuria. Nevertheless, these conditions imply major graft pathologies requiring precise and early detection, as delay in management could herald chronic and relentless course of graft loss.

\section{Urinary Proteome in Renal Allograft Recipient}

In contrast to overt proteinuria, smaller genomic peptides and protein chains ranging from $1000 \mathrm{Da}$ to $20,000 \mathrm{Da}$ present in urine are not detected by usual biochemical and immunological test for urinary protein in the clinical laboratory $[4,17]$. Moreover, these urinary proteomes could be 1000 -fold lower in concentration than that present in plasma and require liquid chromatography (LC) or capillary/column electrophoresis (CE) for separation, mass spectrometry (MS) for detection, and time-of-flight (TOF) measurement for pattern analysis [18].

These urinary proteomes display specific patterns in TOF-MS assay depending on the disease characteristics (Table 2). Urine, collected noninvasively and preserved and prepared with specified standards and protocols, is used in small volume in microliter $(\mu \mathrm{L})$ to identify and characterize large number of peptides and protein chains [4]. Over the current decade, these methodologies resulted in a large pool of discovery and sequencing of previously unexplored proteome in health and various pathologic states as can be explored from various proteome data sources, that is, GenBank, Protein Data Bank (PDB), SwissProt, Protein Information Resource (PIR), Protein Research Foundation (PRF), and so forth $[19,20]$.

\section{Identification of Urinary Proteome}

Techniques for urinary proteome analysis are of two types, gel-based (2-DE and 2D-DIGE) and gel-free (MALDI, SALDI, and iTRAQ) [18, 21, 22]. The gel-based detection of biomarkers is the first dimension isoelectric focusing, separating proteins in electrophoresis strips based on charge selectivity, and the two-dimensional gel electrophoresis (2DE) which is the most widely used approach [21]. Sodium dodecyl sulfate polyacrylamide gel (SDSPAGE) electrophoresis is one common type of 2-DE that separates proteins on molecular size selectivity [13]. A more sensitive and highthroughput gel-based technique termed as two-dimensional 
TABLE 2: Patterns of urinary proteome in different renal allograft dysfunctions.

\begin{tabular}{|c|c|c|c|c|}
\hline & Graft dysfunction & Nature of proteomes & Sources & $\begin{array}{l}\text { Urinary proteome patterns } \\
\text { (molecular weight }(\mathrm{Da}))\end{array}$ \\
\hline 1 & Normal native kidney & Spill over proteomes. & Renal cells. & $\begin{array}{c}\text { Peak at } 9754 . \\
\text { Increased frequency at } \\
1668,1817,1687,1782,1882, \\
\text { and } 2154 .\end{array}$ \\
\hline 2 & Normal renal allograft & $\begin{array}{l}\text { Beta- } 2 \mu \text {-globulin, human } \\
\text { defensin, and so forth. }\end{array}$ & $\begin{array}{l}\text { Passenger cells and spill } \\
\text { over proteomes. }\end{array}$ & $\begin{array}{c}\text { Enhancement at } 3370,3441, \\
\text { 3385, 4303, 4309, } 4449, \\
5090,4139,5627,5563, \\
5459,10350 \text {, and } 11732 \\
\text { (beta- } 2 \mu \text {-globulin). }\end{array}$ \\
\hline
\end{tabular}

\begin{tabular}{|c|c|c|c|c|}
\hline 3 & Acute graft rejection & $\begin{array}{l}\text { Adhesion molecules, } \\
\text { cytokines, perforin, } \\
\text { granzyme, and activation of } \\
\text { complement cascade and } \\
\text { coagulation cascade } \\
\text { peptides and their } \\
\text { degradation products. }\end{array}$ & $\begin{array}{l}\text { APC, B and T-lymphocytes, } \\
\text { NK cells, macrophages, and } \\
\text { so forth. }\end{array}$ & $\begin{array}{l}\text { Enhancement at } 2003,2807 \text {, } \\
4756,5872,6990 \text {, and } 19018 \text {, } \\
25665 .\end{array}$ \\
\hline 4 & Acute tubular necrosis & $\begin{array}{l}\text { NGAL, KIM-1, and } \\
\text { NaHE-3. }\end{array}$ & Tubular epithelial cells. & $\begin{array}{l}\text { Enhancement at } 5500-7500 \\
\text { range and at } 6400,28500 \\
33000,4300 \text {, and } 66000 .\end{array}$ \\
\hline 5 & UTI & & & $\begin{array}{c}2327,5065,3485,16356 \\
4825, \text { and } 6647 .\end{array}$ \\
\hline 6 & CNI toxicity & \multicolumn{3}{|c|}{$\begin{array}{l}\text { Downregulation of extracellular matrix/cell adhesion components and the } \\
\text { upregulation of secreted cyclophilin A and cyclophilin B, macrophage inhibition } \\
\text { factor and phosphatidyl-ethanolamine-binding protein-1, and so forth. }\end{array}$} \\
\hline 7 & CAAR & $\begin{array}{l}\text { Clusters in MS regions, } \\
\text { which are not seen in } \\
\text { healthy urine protein } \\
\text { profile. }\end{array}$ & $\begin{array}{l}\text { EMT cells and } \\
\text { Lymphocytes. }\end{array}$ & $\begin{array}{l}2628 \text { to } 2922,4307 \text { to } 4799 \text {, } \\
\text { and } 8303 \text { to } 8850 \text {. }\end{array}$ \\
\hline 8 & IFTA & & EMT cells and Fibroblasts. & $\begin{array}{l}\text { Significant underexpressed } \\
\text { features in the range of } \\
2850 \text { to } 3050 \text { from that of } \\
\text { CAAR. }\end{array}$ \\
\hline
\end{tabular}

Da: Dalton, CNI: calcineurin inhibitor, CAAR: chronic antibody associated rejection with C4d deposits, IFTA: interstitial nephritis tubular atrophy NGAL: neutrophil-gelatinase-associated-ligand, KIM-1: kidney-injury-molecule-1, NaHE-3: sodium-transporter-at-apical-membrane, APC: antigen-presenting cell, MS: mass spectrometry, and EMT: epithelial-to-mesenchymal transformation.

difference gel electrophoresis (2D-DIGE) has developed in recent years [23]. These gel-based methods are used to identify low, middle, and high molecular weight proteins in urine.

The gel-free method is used to identify the smaller urinary proteins that consist of genomic urinary proteomes present in urine in small quantity [18]. The labeled identification of numerous proteomes using appropriate probe or antibodies is virtually impossible in the general perspectives. Therefore, label-free identification of proteomes of urine using direct liquid chromatography-tandem mass spectrometry (LC-MS) and column/capillary electrophoresis mass spectrometry technique (CE-MS) is used for separation and characterization in terms of their mass and charge $(\mathrm{m} / \mathrm{z})$ characteristics $[7,21,24]$. These methods are based on nongel-based capillary or column electrophoresis using matrix assisted laser desorption-ionization (MALDI) or surface enhanced laser desorption-ionization (SALDI) of peptides placed on protein chips $[7,8]$. Small aliquot of urine in microliter $(\mu \mathrm{L})$ is placed on these protein chips for capillary or column electrophoresis. The proteins are identified by their migration characteristics that depend on their molecular size/charge $(\mathrm{m} / \mathrm{z})$ and time-of-flight (TOF) characteristics. The whole process is abbreviated as CE coupled with MALDITOF-MS or SELDI-TOF-MS [7, 8]. Another very sensitive gel-free technique known as isobaric tags for relative and absolute quantification (iTRAQ) is also a method of choice [22].

As the detailed description of these techniques is beyond the scope of this clinical paper, we have summarized their salient and pertinent features in Table 3 . The details have been described elsewhere $[1,7,13,18,21,23,24]$.

\section{Baseline Sources of Urinary Proteome}

All constitutional renal cells ranging from glomerular podocytes to interstitial fibroblasts could be the sources 
TABLE 3: Salient features of techniques for urinary proteome analysis.

\begin{tabular}{|c|c|c|c|c|c|c|}
\hline & Basic types & Specific techniques & $\begin{array}{l}\text { Proteome types } \\
\text { identified }\end{array}$ & $\begin{array}{l}\text { Specific proteome } \\
\text { identification } \\
\text { probe/methods }\end{array}$ & Advantages & Disadvantages \\
\hline 1 & $\begin{array}{l}\text { Gel-based: } \\
\text { electrophoresis on } \\
\text { paper strip. }\end{array}$ & $\begin{array}{l}\text { (a) Isoelectric focusing, } \\
\text { (b) SDS-PAGE, } \\
\text { (c) 2D-DIGE, }\end{array}$ & $\begin{array}{c}\text { Proteins of } 10 \mathrm{kDa} \\
\text { and above }\end{array}$ & $\begin{array}{l}\text { Western blotting } \\
\quad \text { and } \\
\text { immune-blotting } \\
\text { with specific } \\
\text { antibodies against } \\
\text { specific proteins. }\end{array}$ & $\begin{array}{l}\text { Qualitative } \\
\text { separation of } \\
\text { proteins into low, } \\
\text { middle, and high } \\
\text { molecular weight } \\
\text { protein (10 kDa } \\
\text { and above) }\end{array}$ & $\begin{array}{l}\text { Not often } \\
\text { reproducible, } \\
\text { quantitative } \\
\text { assessment is } \\
\text { difficult. }\end{array}$ \\
\hline 2 & $\begin{array}{l}\text { Gel-free: liquid } \\
\text { chromatography, } \\
\text { column/capillary } \\
\text { electrophoresis } \\
\text { with protein chips. }\end{array}$ & $\begin{array}{l}\text { (a) MALDI-MS-TOF, } \\
\text { (b) SALDI-MS-TOF, } \\
\text { (c) iTRAQ }\end{array}$ & $\begin{array}{l}\text { Peptides and small } \\
\text { protein chains } \\
\text { (less than } 20 \mathrm{kDa} \text { ) }\end{array}$ & $\begin{array}{l}\text { MS with } \\
\text { identification of } \\
m / z \text { pattern. }\end{array}$ & $\begin{array}{l}\text { High throughput. } \\
\text { Multiple peptides } \\
\text { can be assessed } \\
\text { according to } \mathrm{m} / \mathrm{z} \\
\text { chart with possible } \\
\text { identification with } \\
\text { known molecular } \\
\text { weight. }\end{array}$ & $\begin{array}{l}\text { Precise qualitative } \\
\text { and quantitative } \\
\text { isolation of } \\
\text { individual peptide } \\
\text { are not possible. }\end{array}$ \\
\hline
\end{tabular}

SDS-PAGE: sodium dodecyl sulfate polyacrylamide gel electrophoresis, 2D-DIGE: two-dimensional difference gel electrophoresis, MALDI: matrix assisted laser desorption-ionization, SELDI: surface enhanced laser desorption-ionization, MS: mass spectrometry, TOF: time-of-flight, iTRAQ: isobaric tags for relative and absolute quantification, $\mathrm{kDa}$ : kilo Dalton, and $m / z$ : molecular size and charge characteristics.

of baseline urinary proteome. In renal allograft, additional immune-modulating cells that populate the grafted kidney because of host-graft interaction also could be a source of these proteins. Furthermore, selective upregulation and downregulation of these cells add to the additional novel proteins in urine [19]. Proteins released from these cells are recycled by tissue macrophages and tubular epithelial cells. The remaining substances are spilled over to urine and usually do not exceed $0.2 \mathrm{~g} / \mathrm{g}$ of creatinine [4]. Therefore, proteomes are present in urine in the absence of overt proteinuria. Human Kidney and Urine Proteome Project (HKUPP.org) has set up a urine proteome pool of glomerular and tubular origin for a control database [20].

\section{Baseline Proteome Pattern in Renal Transplant}

The initial baseline urine proteome pattern remains fairly stable at different times of stable renal function of an individual, whether transplant or nontransplant. This was demonstrated in normal individuals at different intervals, in kidney donors before and after nephrectomy, and in renal transplant recipient's immediate posttransplant surgery and at later dates of stable graft function [25]. As transplantation is an altered state of homeostasis because of host-graft interaction, the proteome pattern shows unusual components in the mass spectrometry profile even with normal graft function [25]. However, unusual components at certain molecular weight of $3370,3441,3385$ (human defensin), 4303, 10350, and $11732 \mathrm{Da}$ (beta-2-microglobulin) are present in stable renal transplant patients [25]. Over the time, these proteome patterns remain fairly uniform as long as the graft function remains stable $[25,26]$. Contrary to it, different graft dysfunctions could be associated with variations in urinary proteome pattern with the upregulation and downregulation of disease specific cells in renal tissue [26, 27]. This important aspect of proteome analysis indicates that urinary proteome could be a dependable biomarker for the prediction of different graft dysfunctions ahead of histopathological confirmation of graft pathology.

\section{Urinary Proteome Patterns in Allograft Dysfunctions}

7.1. Acute Allograft Rejection (AR). In acute renal allograft rejection, upregulation of major histocompatibility cell (MHC) associated antigens led to the activation of antigen presenting cells (APC), B and T lymphocytes, natural killer cells (NK), tissue macrophages, and other inflammatory cells. These lead to the increased production of adhesion molecules, cytokines, perforin, and granzyme, as well as activation of complement cascade and coagulation cascade proteins, releasing their peptides and protein degradation products [6]. These peptides with several other molecules from apoptotic and necrotic cells produce spectral pattern of urinary proteome that have distinct spikes with higher signal intensity in the capillary or column electrophoresis mass spectrometry (CE-MS) $[6,8]$. As shown in animal model of acute rejection in rat, proteome analysis with MALDI-TOFMS platform revealed differential polypeptides as compared to normal control [27]. In addition, urine proteome analysis by SELDI-TOF-MS platform in allograft acute rejection revealed peptides that included mass (molecular weight) of $2003,2807,4756,5872,6990,19018$, and $25665 \mathrm{Da}$ with sensitivity of $90.5 \%$ and specificity of $77.8 \%$ [28].

7.2. Acute Tubular Necrosis (ATN). Proteome analysis with SELDI-TOF-MS of urine of renal allograft with acute tubular necrosis (ATN) consistently showed spectral patterns of polypeptide biomarkers with molecular weight bands of 
$6300,28500,33000,43000$, and $66000 \mathrm{Da}$ in contrast to lower molecular weight peptides of acute rejection [29]. These small proteins identified in ATN are neutrophil-gelatinaseassociated-ligand (NGAL), kidney-injury-molecule-1 (KIM1), sodium-transporter-at-apical-membrane (NaHE-3), and so forth. Tubular biomarkers like adenosine-deaminase and carbonic-anhydrase-enzyme and spill over proteins like retinol-binding-protein and alpha-1-microglobulin, and so forth, were also included in this group of proteome [30].

7.3. Calcineurin Inhibitor (CNI) Toxicity. Calcineurin inhibitors (CNI) have long been known to have toxic effect on renal allograft. Experiment with cultured human embryonic kidney cells exposed to cyclosporine and tacrolimus showed proteomic perturbation, both intracellular and extracellular, in capillary electrophoresis. Several peptides and small proteins were identified as a result of upregulation of cyclophilin and downregulation of fibronectin [31]. Changes in macrophage activating factor were also identified [31]. In murine model, specific peptides originating from tubular cellular toxicity were also identified [32]. These peptides could be used as potential biomarkers for CNI toxicity.

7.4. Chronic Allograft Dysfunction. Chronic allograft dysfunction is characterized by chronic antibody associated rejection with C4d deposits (CAAR) and interstitial nephritis tubular atrophy (IFTA) most commonly [33]. The other causes of interstitial fibrosis are recurrent glomerulonephritis and transplant glomerulopathy. In these conditions, glomerular podocytes and tubular epithelial cells undergo mesenchymal transformation to form myofibroblast cells in the renal interstitial tissue, known as epithelialto-mesenchymal-transformation (EMT) [34]. Myofibroblast cells derived from EMT lead to interstitial fibrosis in chronic allograft dysfunction. Renal allograft which showed markers of EMT on their podocytes and tubular epithelial cells in higher proportions developed diffuse interstitial fibrosis (IFTA) more frequently at five years after transplant [34]. Paxillin containing adhesion molecules and alpha-smooth muscle actin expression on glomerular podocytes and tubular epithelial cells were upregulated in these groups of transplant patients [34].

Study using label-free identification of urinary proteomes to characterize proteome pattern in CAAR and IFTA revealed significant differences in proteome patterns as compared to that of healthy individuals and renal transplant patients with stable graft function [7]. Using MALDI-TOF mass spectrometry the authors have shown comparative bioinformatics differences in urinary proteome pattern in CAAR, IFTA, stable transplant patients, and healthy individuals [7]. In all cases allergic drug reaction, sepsis, and other inflammatory process leading to graft dysfunction had been clinically excluded. In other studies, proteomes were mapped and characterized by genome wide expression profile in tissues [33]. Multiple sets of proteome with unique expression profile differentiating normal transplant biopsy and biopsies with IFTA and CAAR were mapped and validated, differentiating normal transplant biopsy from the biopsies with IFTA and CAAR [33].

\section{Biomarker Data}

Several works on renal allograft have identified different proteome patterns of urine in acute rejection, acute tubular necrosis, calcineurin toxicity, urinary tract infection, interstitial fibrosis tubular atrophy, and chronic antibody associated rejection. Moreover, studies demonstrated that these proteome patterns of various posttransplant states are distinct from the proteome patterns of the stable transplant recipients and healthy individuals [6-8]. Similarly, differences in urinary proteome patterns have also been demonstrated in native kidney glomerulonephritis [35, 36]. Currently, human urinary proteome project (HKUPP.org) has been updating the proteome pattern of human glomerulus and tubule in normal subjects and proteinuric subjects [20].

\section{Limitations in Urinary Proteome Analysis}

The major limitation in proteomic analysis of urine is the collection, preservation, and preparation of the urine sample, as urine is a biological product which tends to lose the diagnostic biomarkers over time due to degradation by its own protease enzymes and acquired bacterial contaminants. These can be obviated by following standard protocols for sample collection, storage, and preparation, as well as by using standard analytical performances of reliable 2DE, LCMS, and CE-MS protocol described elsewhere $[4,13,18]$. Even though mandatory standards are followed, problems are encountered, particularly with the reproducibility of proteome patterns and noncomparability of data from different groups with divergent approaches. However, systems for organizing the data structure of several proteome pools have also been generated. Various databanks, that is, GenBank, Protein Data Bank (PDB), SwissProt, Protein Information Resource (PIR) and Protein Research Foundation (PRF), and so forth, have proposed unique hierarchical tree that yields high-quality proteome families that could bring harmony in data pool for disease prediction [10]. Last but not least, appropriate and user-friendly bioinformatics software for data evaluation, together with a formatted data bank as mentioned above, could eliminate the hindrance toward a globally approached and universally accepted system of urinary proteome analysis that could bring uniformity in disease prediction in this regard [37].

Hence a centralized proteome database could be of value for clinical application. A data sharing platform for data collection and integration from all urinary proteome projects could help to unify the urinary proteomes for collective use.

\section{Conclusions}

The voided urine of renal allograft recipient contains proteomes that have multiple sources based on allograft pathology. Consequently, the urinary proteome pattern analysis might differentiate the various graft abnormalities at 
an early stage of graft dysfunction. Conventional investigations including transplant biopsy to confirm the diagnosis require time and involve risk. Furthermore, delay in the diagnosis could lead to the progression of allograft dysfunction. Therefore, early intervention and amelioration of the graft dysfunction could be achieved by early prediction of AR, ATN, CNI toxicity, CAAR, and IFTA with the help of this novel approach of urinary proteome analysis.

\section{Conflict of Interests}

The author declares that there is no conflict of interests regarding the publication of this paper.

\section{Acknowledgment}

This review paper was written as a part of the study on "Impact of proteinuria pattern on renal allograft function and survival" that was approved by the Institutional Review Board (IRB), Singhealth, Singapore (Reference no. 2009/648/E).

\section{References}

[1] M. K. Shamseddin and G. A. Knoll, "Posttransplantation proteinuria: an approach to diagnosis and management," Clinical Journal of the American Society of Nephrology, vol. 6, no. 7, pp. 1786-1793, 2011.

[2] S. M. Suhail, T. S. Y. Kee, K. T. Woo et al., "Impact of patterns of proteinuria on renal allograft function and survival: a prospective cohort study," Clinical Transplantation, vol. 25, no. 3, pp. E297-E303, 2011.

[3] L. C. Racusen, K. Solez, R. B. Colvin et al., "The Banff 97 working classification of renal allograft pathology," Kidney International, vol. 55, no. 2, pp. 713-723, 1999.

[4] B. A. Julian, H. Suzuki, Y. Suzuki, Y. Tomino, G. Spasovski, and J. Novak, "Sources of urinary proteins and their analysis by urinary proteomics for the detection of biomarkers of disease," Proteomics, vol. 3, no. 9, pp. 1029-1043, 2009.

[5] P. Nickerson and P. S. Heeger, "Proteomic portrayal of transplant pathologies," Journal of the American Society of Nephrology, vol. 20, no. 2, pp. 236-238, 2009.

[6] S. Wittkea, M. Haubitzb, M. Waldena et al., "Detection of acute tubulointerstitial rejection by proteomic analysis of urinary samples in renal transplant recipients," The American Journal of Transplantation, vol. 5, pp. 2479-2488, 2005.

[7] L. F. Quintana, A. Solé-Gonzalez, S. G. Kalko et al., "Urine proteomics to detect biomarkers for chronic allograft dysfunction," Journal of the American Society of Nephrology, vol. 20, no. 2, pp. 428-435, 2009.

[8] S. Schaub, D. Rush, J. Wilkins et al., "Proteomic-based detection of urine proteins associated with acute renal allograft rejection," Journal of the American Society of Nephrology, vol. 15, no. 1, pp. 219-227, 2004.

[9] http://www.ebi.ac.uk/ebisearch/search.ebi?db=medline\&t= urine+proteome.

[10] http://www.protonet.cs.huji.ac.il.

[11] M. Myslak, H. Amer, P. Morales et al., "Interpreting posttransplant proteinuria in patients with proteinuria pretransplant," The American Journal of Transplantation, vol. 6, no. 7, pp. 1660-1665, 2006.
[12] G. Fernández-Fresnedo, J. J. Plaza, J. Sánchez-Plumed, A. SanzGuajardo, R. Palomar-Fontanet, and M. Arias, "Proteinuria: a new marker of long-term graft and patient survival in kidney transplantation," Nephrology Dialysis Transplantation, vol. 19, no. 3, pp. iii47-iii51, 2004.

[13] M. T. Pires, A. Santinho da Cunha, G. Virella, and J. Simoes, "Analytical characterization of urinary proteins by sodium dodecyl sulphate polyacrylamide gel electrophoresis in renal disease: clinical and histopathological correlations," Nephron, vol. 14, no. 5, pp. 361-372, 1975.

[14] C. Donadio, R. Puccini, A. Lucchesi, R. Giordani, and G. Rizzo, "Urinary excretion of proteins and tubular enzymes in renal transplant patients," Renal Failure, vol. 20, no. 5, pp. 707-715, 1998.

[15] J. Fotheringham, C. A. Angel, and W. McKane, "Transplant glomerulopathy: morphology, associations and mechanism," Nephron, vol. 113, no. 1, pp. cl-c7, 2009.

[16] P. Hribova, J. Lacha, K. Kotsch et al., "Intrarenal cytokine and chemokine gene expression and kidney graft outcome," Kidney and Blood Pressure Research, vol. 30, no. 5, pp. 273-282, 2007.

[17] H. Mischak, C. Delles, J. Klein, and J. P. Schanstra, "Urinary proteomics based on capillary electrophoresis-coupled mass spectrometry in kidney disease: discovery and validation of biomarkers, and clinical application," Advances in Chronic Kidney Disease, vol. 17, no. 6, pp. 493-506, 2010.

[18] H. Dihazi and G. A. Müller, "Urinary proteomics: a tool to discover biomarkers of kidney diseases," Expert Review of Proteomics, vol. 4, no. 1, pp. 39-50, 2007.

[19] G. H. Tesch, "Review: serum and urine biomarkers of kidney disease: a pathophysiological perspective," Nephrology, vol. 15, no. 6, pp. 609-616, 2010.

[20] T. Yamamoto, R. G. Langham, P. Ronco, M. A. Knepper, and V. Thongboonkerd, “Towards standard protocols and guidelines for urine proteomics: a report on the Human Kidney and Urine Proteome Project (HKUPP)," Proteomics, vol. 8, no. 11, pp. 21562159, 2008.

[21] J. F. Timms and R. Cramer, "Difference gel electrophoresis," Proteomics, vol. 8, no. 23-24, pp. 4886-4897, 2008.

[22] P. L. Ross, Y. N. Huang, J. N. Marchese et al., "Multiplexed protein quantitation in Saccharomyces cerevisiae using aminereactive isobaric tagging reagents," Molecular and Cellular Proteomics, vol. 3, no. 12, pp. 1154-1169, 2004.

[23] P. Meleady, "2D gel electrophoresis and mass spectrometry identification and analysis of proteins," Methods in Molecular Biology, vol. 784, pp. 123-137, 2011.

[24] C. Spahr, M. Davis, M. D. McGinley et al., "Towards defining the urinary proteome using liquid chromatography-tandem mass spectrometry I: profiling an unfractionated tryptic digest," Proteomics, vol. 1, no. 1, pp. 93-107, 2001.

[25] S. K. Akkina, Y. Zhang, G. L. Nelsestuen, W. S. Oetting, and H. N. Ibrahim, "Temporal stability of the urinary proteome after kidney transplant: more sensitive than protein composition?" Journal of Proteome Research, vol. 8, no. 1, pp. 94-103, 2009.

[26] L. F. Quintana, E. Bañon-Maneus, A. Solé-Gonzalez, and J. M. Campistol, "Urine proteomics biomarkers in renal transplantation: an overview," Transplantation, vol. 88, no. 3, pp. S45-S49, 2009.

[27] Y. Dai, T. Lv, K. Wang, Y. Huang, D. Li, and J. Liu, "Detection of acute renal allograft rejection by analysis of renal tissue proteomics in rat models of renal transplantation," Saudi Journal of Kidney Diseases and Transplantation, vol. 19, no. 6, pp. 952-959, 2008. 
[28] E. O’Riordan, T. N. Orlova, M. J. Jianfeng et al., "Bioinformatic analysis of the urine proteome of acute allograft rejection," Journal of the American Society of Nephrology, vol. 15, no. 12, pp. 3240-3248, 2004.

[29] D. Prasad, "Novel biomarkers for the early prediction of acute kidney injury," Cancer Therapy, vol. 3, pp. 477-488, 2005.

[30] K. Bramham, H. D. Mistry, L. Poston, L. C. Chappell, and A. J. Thompson, "The non-invasive biopsy: will urinary proteomics make the renal tissue biopsy redundant?" QJM, vol. 102, no. 8, pp. 523-538, 2009.

[31] F. Lamoureux, L. N. Gastinel, E. Mestre, P. Marquet, and M. Essig, "Mapping cyclosporine-induced changes in protein secretion by renal cells using stable isotope labeling with amino acids in cell culture (SILAC)," Journal of Proteomics, vol. 27, pp. 3674-3687, 2012.

[32] S. O'Connell, C. Slattery, M. P. Ryan, and T. McMorrow, "Identification of novel indicators of cyclosporine A nephrotoxicity in a CD-1 mouse model," Toxicology and Applied Pharmacology, vol. 252, no. 2, pp. 201-210, 2011.

[33] A. Nakorchevsky, J. A. Hewel, S. M. Kurian et al., "Molecular mechanisms of chronic kidney transplant rejection via largescale proteogenomic analysis of tissue biopsies," Journal of the American Society of Nephrology, vol. 21, no. 2, pp. 362-373, 2010.

[34] B. H. Özdemir, A. A. Özdemir, T. Colak, S. Sezer, and M. Haberal, "The influence of tubular phenotypic changes on the development of diffuse interstitial fibrosis in renal allografts," Transplantation Proceedings, vol. 43, no. 2, pp. 527-529, 2011.

[35] B. A. Julian, S. Wittke, M. Haubitz et al., "Urinary biomarkers of IgA nephropathy and other IgA-associated renal diseases," World Journal of Urology, vol. 25, no. 5, pp. 467-476, 2007.

[36] S. Decramer, A. G. de Peredo, B. Breuil et al., "Urine in clinical proteomics," Molecular and Cellular Proteomics, vol. 7, no. 10, pp. 1850-1862, 2008.

[37] D. Fliser, J. Novak, V. Thongboonkerd et al., "Advances in urinary proteome analysis and biomarker discovery," Journal of the American Society of Nephrology, vol. 18, no. 4, pp. 1057-1071, 2007. 


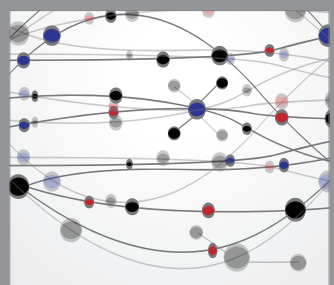

The Scientific World Journal
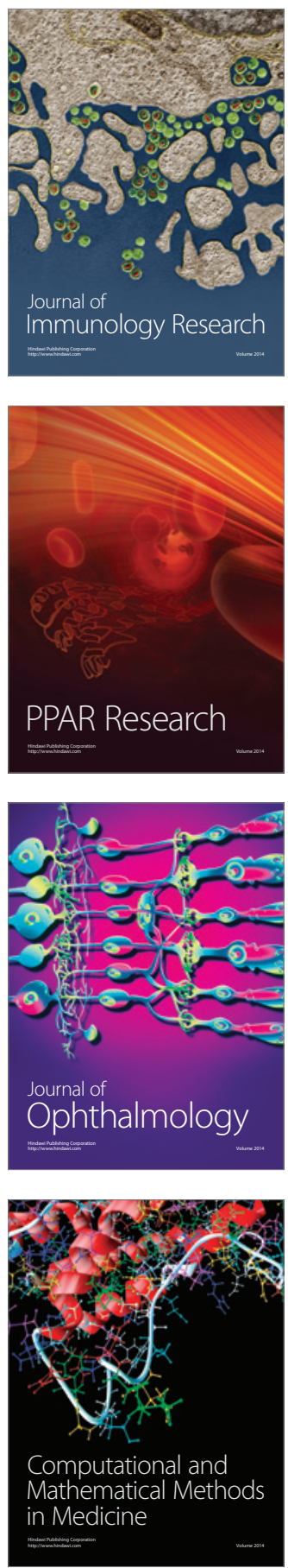

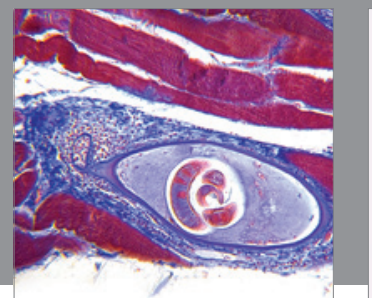

Gastroenterology

Research and Practice
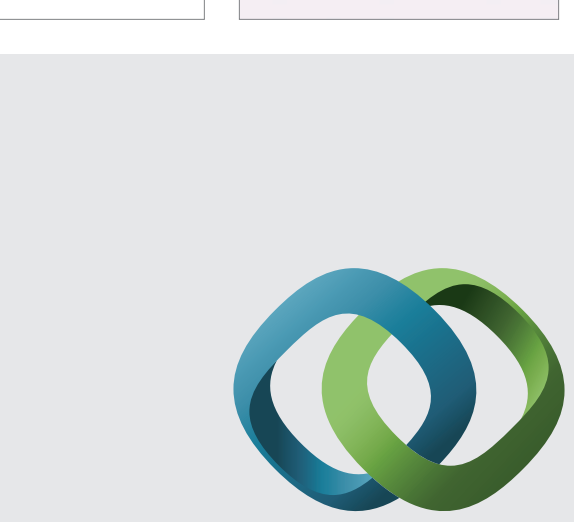

\section{Hindawi}

Submit your manuscripts at

http://www.hindawi.com
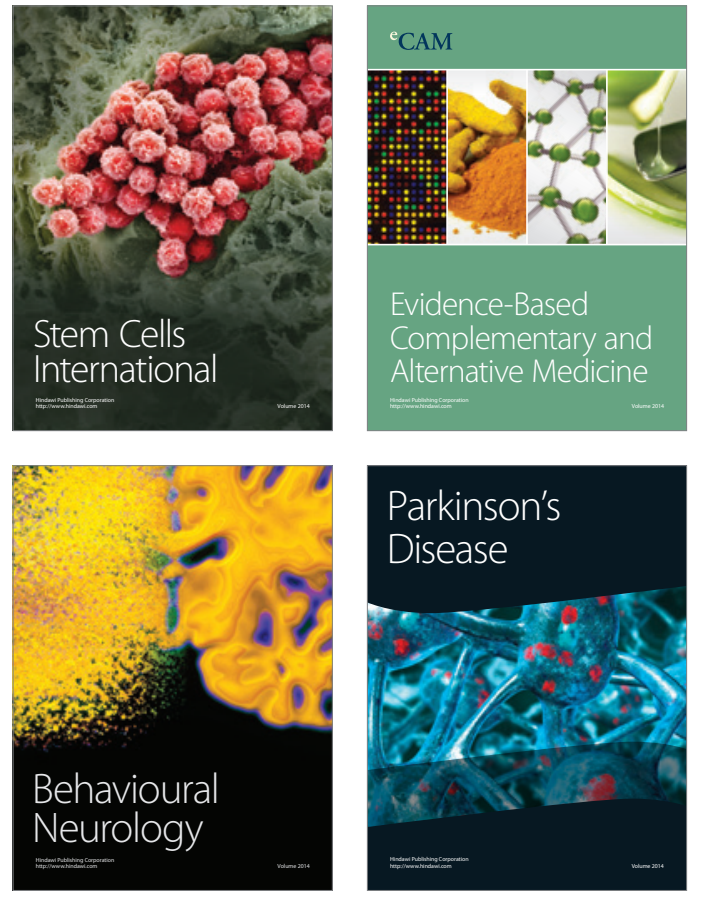
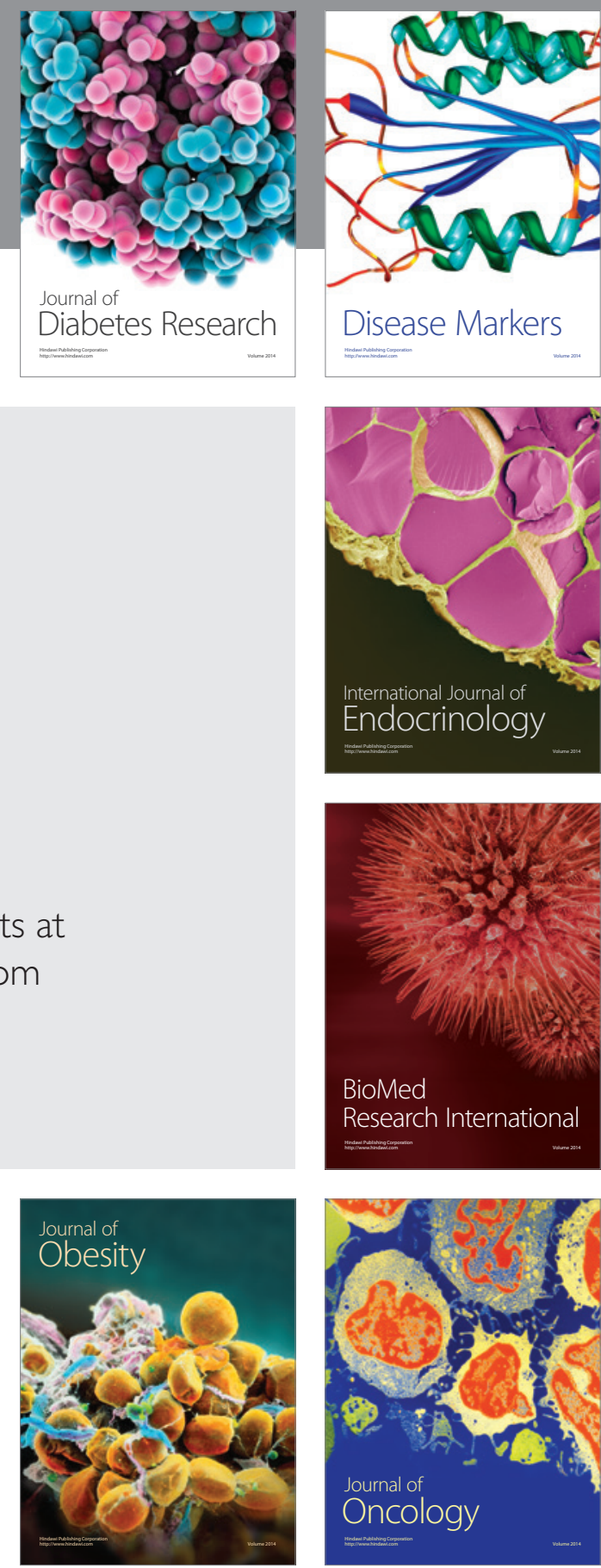

Disease Markers
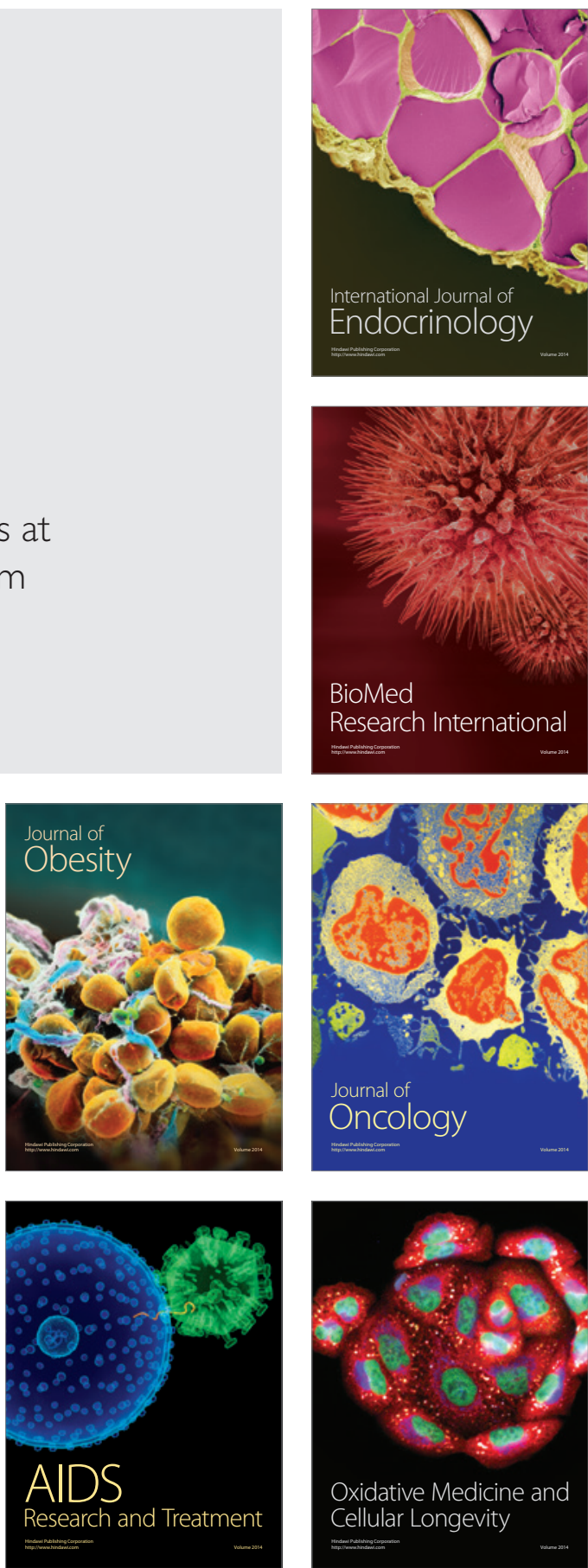